\title{
Synthesis and properties of doped ZnO ceramics
}

\begin{abstract}
In our work, we studied zinc oxide ceramic samples doped with aluminum and gallium. Structure peculiarities of ceramics depending on their synthesis regime were investigated by the SEM, EDX, XRD, and Raman spectroscopy methods. It was demonstrated that at some technological conditions the formation of indesirable phases of zinc aluminate or gallate may occur preventing an uniform material doping and reducing quality of samples. Single-phase $\mathrm{ZnO}$ ceramics were produced when the nanostructured alumina powders were used as a dopant source. The correlations between the synthesis regimes of $\mathrm{ZnO}$ ceramics and their electrophysical parameters essential for thermoelectric figure-of-merit (electrical conductivity and Seebeck coefficient) have been established. The best electrophysical characteristics were obtained when the nanostructured alumina produced by combustion in isopropyl alcohol was used as a dopant. Conductivity and Seebeck coefficient of such ceramics are equal to $3 \cdot 10^{3} \mathrm{~S} / \mathrm{m}$ and $-0.27 \mathrm{mV} / \mathrm{K}$, respectively, corresponding to the power factor of $2.2 \cdot 10^{-4} \mathrm{~W} /\left(\mathrm{m} \cdot \mathrm{K}^{2}\right)$.
\end{abstract}

Streszczenie. W naszej pracy zbadaliśmy próbki ceramiki tlenku cynku domieszkowanej aluminium oraz galem. Specyfike struktury ceramiki zależącą od warunków syntezy zbadano metodami SEM, EDX, XRD oraz spektroskopią Ramana. Zaprezentowano, że dla niektórych warunków technologicznych tworzą się niepożądane fazy glinianu cynku lub galusanu zapobiegając jednolitemu domieszkowaniu materiału oraz zmniejszając jakość próbek. Jednofazowa ceramika ZnO została uzyskana w czasie, gdy nanostrukturalny proszek tlenku aluminium był używany jako źródło domieszki. Określono powiązania pomiędzy warunkami otrzymywania ceramiki ZnO oraz jej elektro-fizycznymi parametrami niezbędnymi do termoelektrycznego współczynnika jakości (przewodnictwo elektryczne oraz współczynnik Seebeck’a). Najlepsze elektrofizyczne charakterystyki otrzymano, gdy używano jako domieszkę nanostrukturalny tlenek aluminium produkowany poprzez spalanie w alkoholu izopropylowym. Przewodność oraz współczynnik Seebeck’a tego typu ceramik wynosi odpowiednio 3.10 $3 / \mathrm{m}$ oraz -0.27 mV/K, co odpowiada współczynnikowi mocy równemu $2.2 \cdot 10^{-4} \mathrm{~W} /\left(\mathrm{m} \cdot \mathrm{K}^{2}\right)$. (Synteza i właściwości domieszkowanej ceramiki ZnO).

Keywords: $\mathrm{ZnO}$, ceramics, doping, structure, electrical properties.

Słowa kluczowe: $\mathrm{ZnO}$, ceramika, domieszkowanie, struktura, właściwości elektryczne.

\section{Introduction}

Great attention is paid today to the study of materials suitable for thermoelectric energy conversion. As is known, for efficient thermoelectric conversion it is necessary to use materials with high values of conductivity and Seebeck coefficient as well as low thermal conductivity [1]. Zinc oxide is one of the most promising materials for thermoelectric converters. Its advantages are relative availability of zinc, nontoxicity, resistance to oxidation and, consequently, possibility of use at high temperatures.

Zinc oxide is a wide-gap semiconductor with the bandgap equal to approximately $3.2 \mathrm{eV}$. For a long period of time it was used mainly for the fabrication of varistors. However, in recent years, the greatest interest in zinc oxide is related to optoelectronics [2 - 4]. Zinc oxide is characterized by relatively high Seebeck coefficient (up to $350 \mu \mathrm{V} / \mathrm{K}$ at high level of doping). However, its use in thermoelectric applications is limited today because of relatively high thermal conductivity as well as technological difficulty of doping. Despite the efforts made by researchers over the last decades, it is still not possible to obtain highquality heavily doped p-type zinc oxide. Therefore, n-type zinc oxide is used to create the thermoelectric transducers. The most common dopants are such elements as $\mathrm{Al}, \mathrm{In}, \mathrm{Sb}$, $\mathrm{Ga}[5-8]$. In so doing, keeping of acceptable values of thermal conductivity and Seebeck coefficient is also a challenge. The aim of this study is to determine the influence of type of dopant sources on the thermoelectric characteristics of zinc oxide.

\section{Experimental}

Synthesis of ceramics. A commercial zinc oxide powder consisting of needle-shaped particles with an average length of $0.2-0.5 \mathrm{~mm}$ and diameter of $50 \mu \mathrm{m}$ was used. Nanostructured $\mathrm{Al}_{2} \mathrm{O}_{3}$ obtained in P.O. Sukhoi State Technical University of Gomel by burning of aluminum nitrate in isopropyl alcohol or saccharose was used for doping of ceramics by aluminium. A commercial $\mathrm{Ga}_{2} \mathrm{O}_{3}$ powder was used for doping of $\mathrm{ZnO}$ ceramics by gallium.
A convenient muffler or a microwave oven with a maximum microwave power of $800 \mathrm{~W}$ were used for the synthesis of ceramics. Zinc oxide powder with alumina (gallium oxide) powder were carefully triturated in a porcelain mortar with ethanol. Then the half-dry mixture (moisture of $15-18 \%$ ) was mixed with a $3 \%$ PVA solution and placed in a mold (diameter of $10 \mathrm{~mm}$ ), where it was subjected to a semi-dry compaction under pressure of $100 \mathrm{MPa}$. After removal from the mold, the samples were dried in an oven at $60{ }^{\circ} \mathrm{C}$ for $0.5 \mathrm{~h}$. The dried cylindrical blanks were heat treated in a muffler. The temp of the temperature growth was $800^{\circ} \mathrm{C} / \mathrm{h}$, and the duration of soaking at the maximal temperature of $1200^{\circ} \mathrm{C}$ was $3-6 \mathrm{~h}$. The total time of process did not exceed $18 \mathrm{~h}$. A part of the pressed samples were placed into $800 \mathrm{~W}$ microwave oven and sintered in a silicon carbide powder bitstone that absorbs microwaves.

Characterization of ceramics. X-ray analysis was carried out with a Rigaku ULTIMA IV diffractometer (BraggBrentano geometry, $\mathrm{Cu} \mathrm{Ka}$ emission, 0.5 deg./min). Scanning electron microscopy (SEM) and Energy-dispersive X-ray (EDX) analysis were realized with a LEO 1455 VP microscope. Raman spectra were measured using a Nanofinder HE confocal spectrometer (Lotis TII, Belarus Japan) with a $473 \mathrm{~nm}$ solid-state laser as an excitation source. Incident optical power was attenuated to a few hundreds of microwatts to minimize a thermal impact on the samples. Back-scattered light without analysis of its polarization was dispersed with a spectral resolution of $3 \mathrm{~cm}^{-1}$ and detected with a cooled CCD-matrix.

The resistivity of the samples was determined from their current-voltage characteristics measured using the standard 4-probe method. For measurement of Seebeck effect, the temperature gradient about $10-15 \mathrm{~K}$ was created along the sample. ThermoEMF was measured by nanovoltmeter as a function of temperature difference between the "hot" and "cold" sample edges. Seebeck coefficient was calculated by differentiation of the experimental dependence of thermoEMF on the temperature difference on the sample. 


\section{Results and Discussion}

\subsection{Structure of undoped $\mathrm{ZnO}$ ceramics}

Typical heat treatment conditions, as well as results of primary characterization of the aluminum doped zinc oxide ceramics obtained using muffler or microwave oven are presented in Table 1.

Table 1. Characteristics of zinc oxide ceramics obtained at different sintering regimes

\begin{tabular}{|c|c|c|c|c|}
\hline Dopant & $\begin{array}{c}\text { Bitstone } \\
\text { composition }\end{array}$ & $\begin{array}{c}\text { Heat } \\
\text { treatment }\end{array}$ & $\begin{array}{c}\text { Density } \\
\text { of } \\
\text { ceramics, } \\
\mathrm{g} / \mathrm{cm}^{3}\end{array}$ & Notes \\
\hline $\begin{array}{c}\mathrm{Al}_{2} \mathrm{O}_{3}, \\
\text { burning in } \\
\text { isopropanol }\end{array}$ & $\mathrm{SiC}$ & $\begin{array}{c}\text { Microwave } \\
\text { oven, } 800 \mathrm{~W}, \\
25 \mathrm{~min}\end{array}$ & 3.38 & $\begin{array}{c}\text { Partial } \\
\text { sintering }\end{array}$ \\
\hline $\begin{array}{c}\mathrm{Al}_{2} \mathrm{O}_{3}, \\
\text { burning in } \\
\text { isopropanol }\end{array}$ & No bitstone & $\begin{array}{c}\text { Muffler, } \\
1200^{\circ} \mathrm{C}, 3 \mathrm{~h}\end{array}$ & 4.75 & Dense \\
\hline $\begin{array}{c}\mathrm{Al}_{2} \mathrm{O}_{3}, \\
\text { burning in } \\
\text { isopropanol }\end{array}$ & No bitstone & $\begin{array}{c}\text { Muffler, } \\
120{ }^{\circ} \mathrm{C}, 6 \mathrm{~h}\end{array}$ & 5.10 & $\begin{array}{c}\text { High- } \\
\text { dense }\end{array}$ \\
\hline $\begin{array}{c}\mathrm{Al}_{2} \mathrm{O}_{3}, \\
\text { burning in } \\
\text { saccharose }\end{array}$ & No bitstone & $\begin{array}{c}\text { Muffler, } \\
1200{ }^{\circ} \mathrm{C}, 6 \mathrm{~h}\end{array}$ & 4.76 & Dense \\
\hline
\end{tabular}

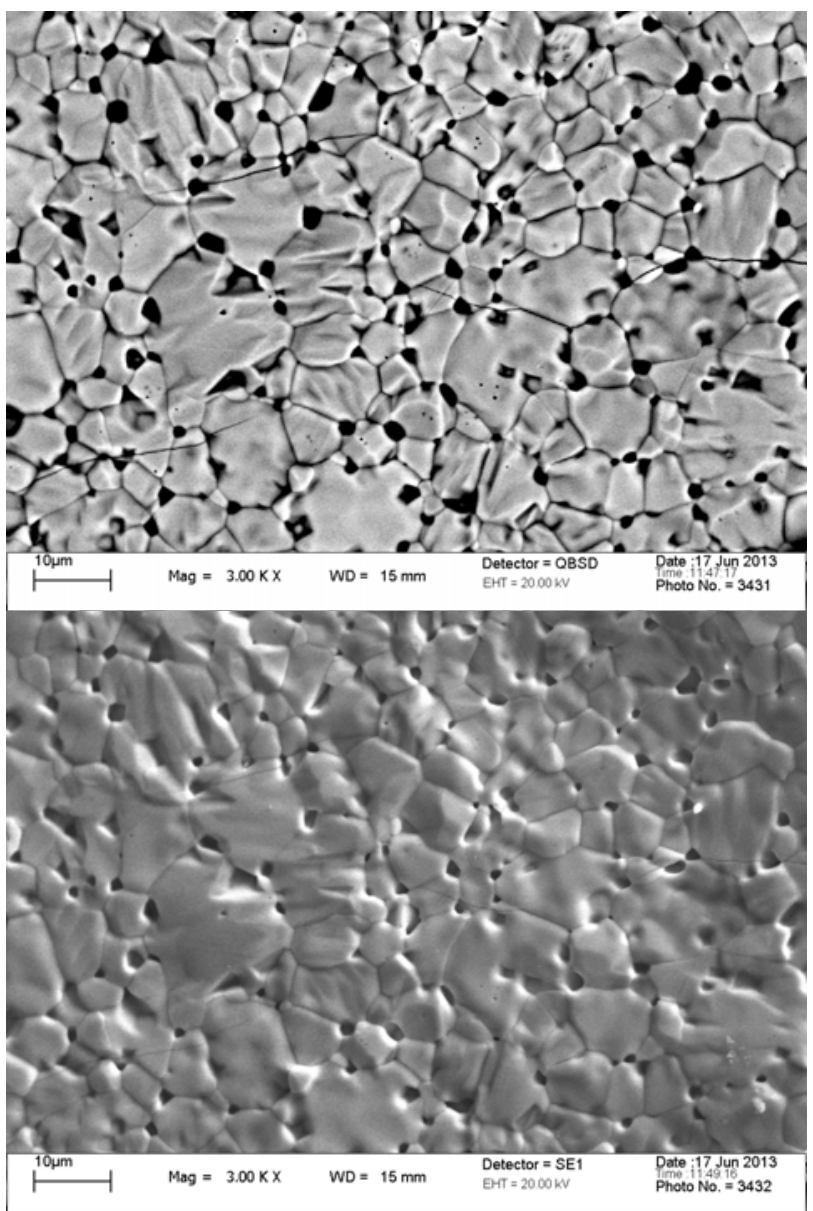

Fig.1. Typical SEM images of undoped $\mathrm{ZnO}$ ceramics (on the left back-scattering electron detection mode; on the right - secondary electron detection mode)

Figure 1 shows typical SEM images for the undoped ZnOceramic. As is seen, the ceramics are formed by grains with the size of a few micrometers. There is practically no contrast within individual grains that indicates a uniform distribution of components therein.The performed EDX analysis showed the absence of any elements other than $\mathrm{Zn}$ and $\mathrm{O}$ in the undoped ceramics. The concentration of zinc atoms within the framework of experimental error equals to the concentration of oxygen atoms.

Figure 2 demonstrates typical $X$-ray diffraction pattern and Raman spectrum for undoped $\mathrm{ZnO}$ ceramics.
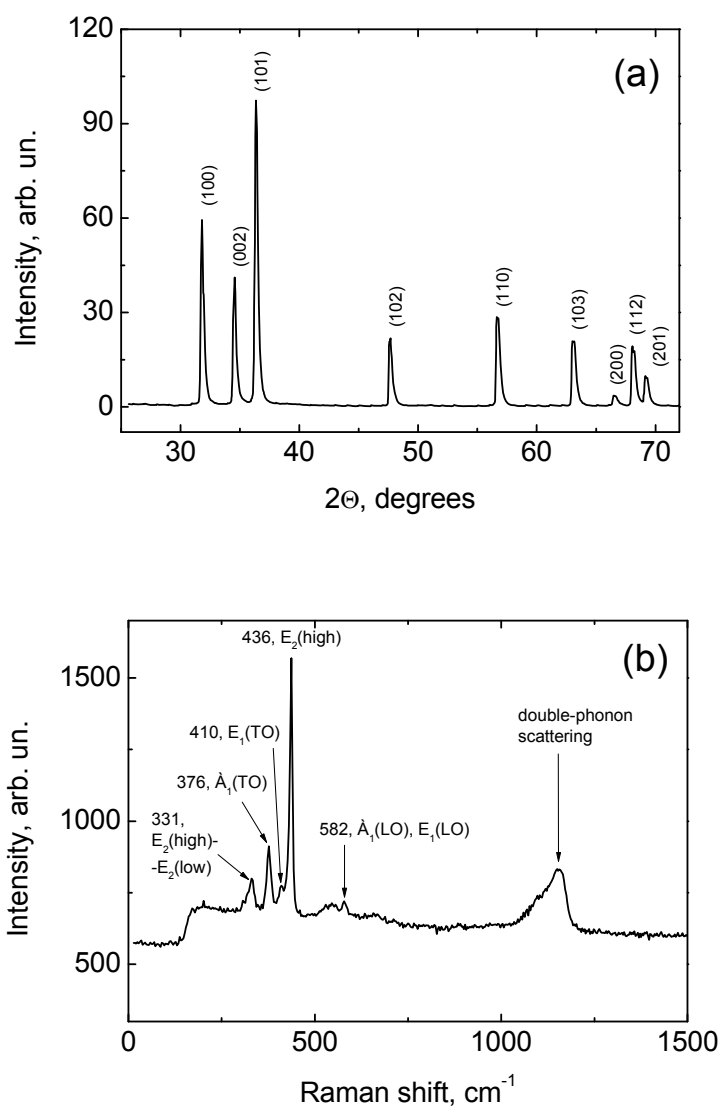

Fig.2.Typical X-ray diffraction pattern (a) and Raman spectrum (b) of undoped $\mathrm{ZnO}$ ceramics

Analysis of diffraction patterns has demonstrated that the observed reflexes correspond to (100), (002), (101), (102), (110), (103), (200), (112), and (201) plain families of the hexagonal zinc oxide indicating a phase purity of the synthesized material. The peak intensity ratio points to absence of the dominant texture.

In Raman spectra of undoped ceramics all peaks correspond to scattering on $\mathrm{ZnO}$ phonons. The observed small (a few $\mathrm{cm}^{-1}$ ) difference between Raman peak positions in our experiments and by other researchers [9] can be naturally explained by difference in elastic stresses and local sample temperature during Raman spectra measurement. One-phonon bands in the Raman spectra have a rather small spectral width (about $10 \mathrm{~cm}^{-1}$ ) indicating a high degree of material quality.

\subsection{Structure and electrical properties of doped $\mathrm{ZnO}$ ceramics}

Figure 3 shows SEM images of aluminum and gallium doped $\mathrm{ZnO}$ ceramics. As can be seen, in the case of $\mathrm{Al}$ doping (Fig. 3a), along with bright grains of dominant phase with the size of several micrometers, there are dark inclusions of about 10 micrometers. Their darker color in the back-scattered electron detection mode indicates enrichment by lighter elements (Al) being in agreement with EDX results.

As is seen from Fig. $3 b$, in the gallium doped ceramics there are two types of grains. Along with dominant grains (globules) of approximately spherical shape also the lamellar grains present. The lack of contrast in the back- 
scattered electron detection mode does not mean composition uniformity since zinc and gallium have close atomic numbers.
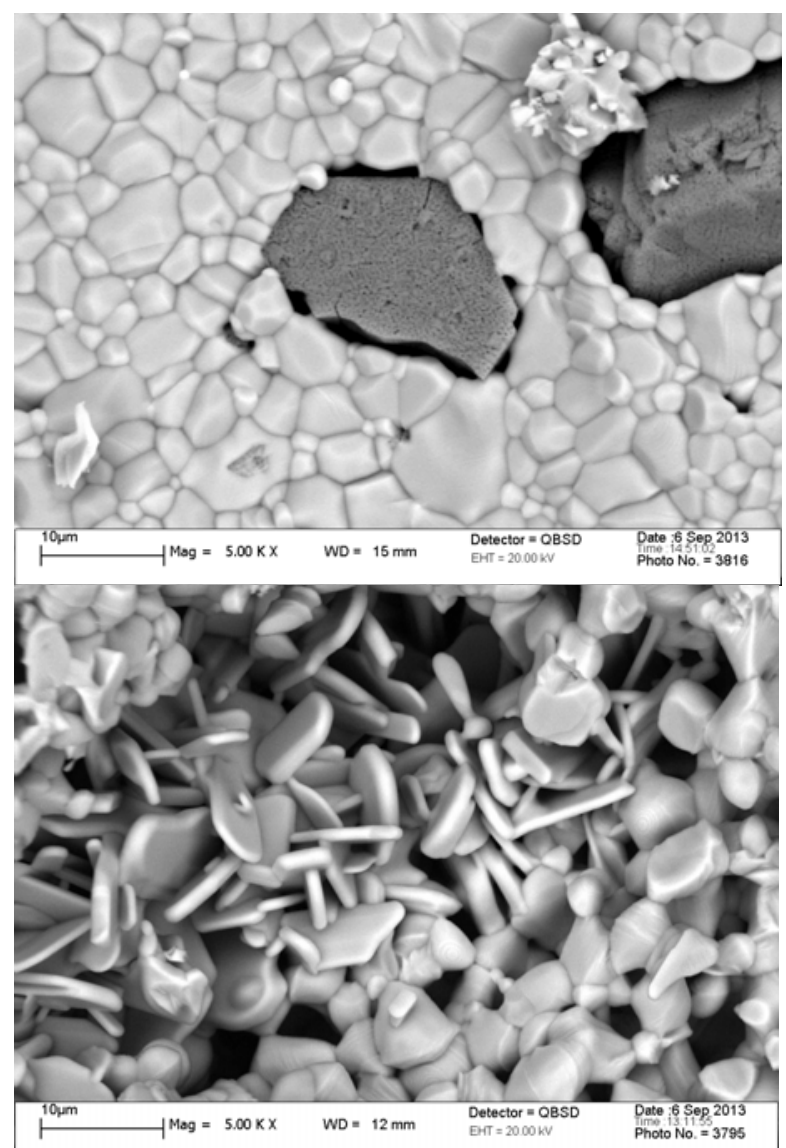

Fig.3. SEM images of Al- (on the left) and Ga-doped (on the right) $\mathrm{ZnO}$ ceramics

The possibility of formation of additional phases in the case of aluminum and gallium doping is confirmed by the Raman spectra measured under excitation of dopantenriched regions (Fig. 4).

Thus, the lack of thorough mixing of the particles of the main phase $(\mathrm{ZnO})$ and dopant source prior to synthesis, as well as not enough temperature and (or) duration of ceramics heat treatment may be reasons for their microheterogeneity and ineffective penetration of the impurity atoms into the $\mathrm{ZnO}$ lattice.

Measurements of current-voltage characteristics of the synthesized ceramics enabled one to calculate their conductivity. Experiments have shown that for undoped ceramics conductivity is about $10 \mathrm{~S} / \mathrm{m}$ (Table 2). The efficiency of electrical conductivity elevation by aluminum and gallium doping depends essentially on the method of introducing of impurities. It has been experimentally established that in the case of impurity introduction followed by formation of the aluminum- or gallium-enriched precipitates discussed above, the electrical conductivity is almost unchanged. The best results have been obtained using nanostructured dopant sources. In the case of introduction of aluminum from nanostructured alumina obtained by burning in isopropyl alcohol, the conductivity was about $3 \cdot 10^{3} \mathrm{~S} / \mathrm{m}$.

ThermoEMF measurements showed that the Seebeck coefficient independing of the used synthesis regimes is negative and its absolute value is equal to $0.54-0.75 \mathrm{mV} / \mathrm{K}$ for the undoped ceramic. Introduction of aluminum and gallium leads to decrease in absolute value of the Seebeck coefficient. For the samples with the highest electrical conductivity the Seebeck coefficient was of $0.26-0.27 \mathrm{mV} / \mathrm{K}$ corresponding to the power factor $2.2 \cdot 10^{-4} \mathrm{~W} /\left(\mathrm{m} \cdot \mathrm{K}^{2}\right)$.
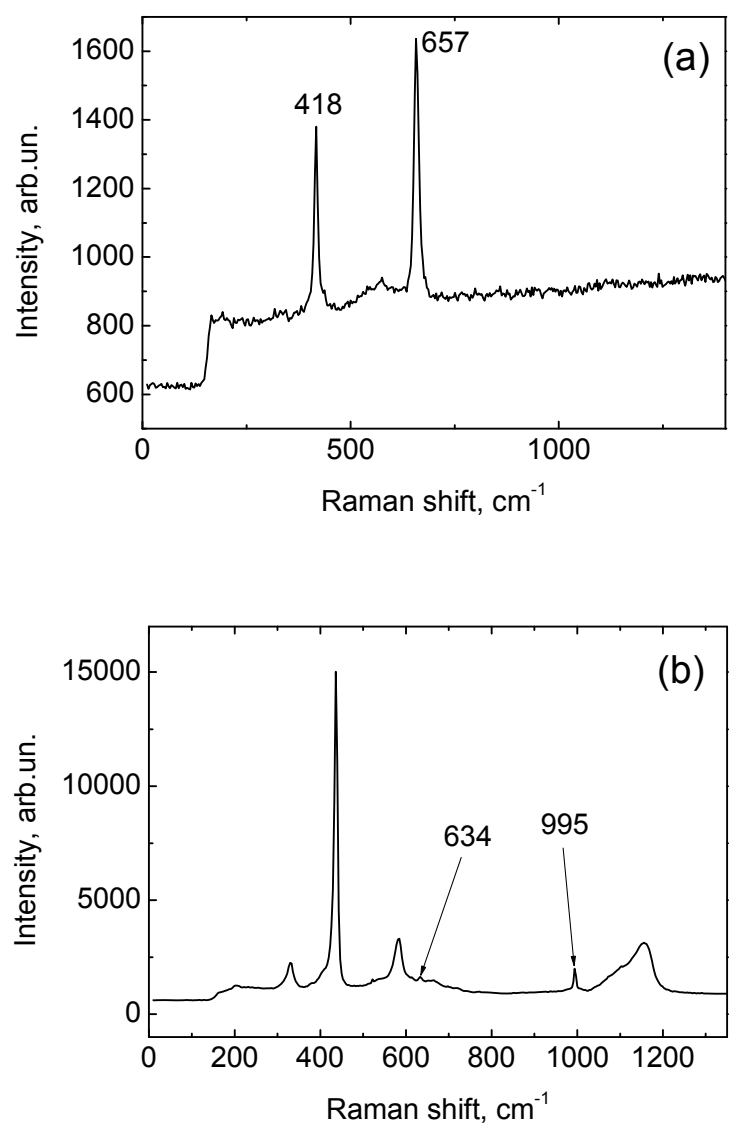

Fig.4. Raman spectra measured under excitation of dopantenriched regions of Al- (a)and Ga-doped (b) ZnO ceramics

Table 2. Electrical characteristics ofz inc oxide ceramics

\begin{tabular}{|c|c|c|c|}
\hline Sample & $\begin{array}{c}\text { Conductivity } \\
{[\mathrm{S} / \mathrm{m}]}\end{array}$ & $\begin{array}{c}\text { Seebeck } \\
\text { coefficient } \\
{[\mathrm{mV} / \mathrm{K}]}\end{array}$ & $\begin{array}{c}\text { Power factor } \\
{\left[\mathrm{W} /\left(\mathrm{m} \cdot \mathrm{K}^{2}\right)\right]}\end{array}$ \\
\hline Undoped & 10 & -0.54 & $2.9 \cdot 10^{-6}$ \\
\hline $\begin{array}{c}\text { Al-doped } \\
\text { (combustion } \\
\text { in isopropyl } \\
\text { alcohol) }\end{array}$ & $3 \cdot 10^{3}$ & -0.27 & $2.2 \cdot 10^{-4}$ \\
\hline
\end{tabular}

\section{Conclusions}

Structure peculiarities of the aluminium and gallium doped $\mathrm{ZnO}$ ceramics were established depending on the synthesis conditions by the Scanning Electron Microscopy, X-ray diffraction, and Raman spectroscopy methods. It is shown that certain technological regimes lead to formation of unwanted phases of zinc aluminate and gallate, which impede an effective doping of ceramics. $\mathrm{ZnO}$ single phase ceramics have been prepared using a nanostructured alumina powders as a dopant source. Regularities in influence of the synthesis conditions of $\mathrm{ZnO}$ ceramics on their electrical properties determining thermoelectric figureof-merit (conductivity and Seebeck coefficient) were established. The best electrical characteristics were achieved by using a nanostructured alumina obtained by burning in isopropyl alcohol as a dopant source. The resistivity and Seebeck coefficient of such ceramics are respectively equal to $3.3 \cdot 10^{-4} \mathrm{Ohm} \cdot \mathrm{m}$ and $-0.27 \mathrm{mV} / \mathrm{K}$ corresponding to the power factor of $2.2 \cdot 10^{-4} \mathrm{~W} /\left(\mathrm{m} \cdot \mathrm{K}^{2}\right)$. 
Authors: Evgheni N. Poddenezhny, Natalie E. Drobishevskaya, P.O. Sukhoi, State Technical University of Gomel, 48 Oktyabria Pr., Gomel, Belarus; Aleksander V. Mazanik, Olga V. Korolik, Aleksander S. Fedotov, Aleksander.K. Fedotov, Ivan A. Svito, Belarusian State University, 4, Nezavisimosti av., 220030 Minsk Belarus, E-mail: fedotov.alehandro@gmail.com; Tomasz N. Koltunowicz, Lublin University of Technology, 38d, Nadbystrzycka Str., 20-618 Lublin, Poland, E-mail: t.koltunowicz@pollub.pl.

\section{REFERENCES}

[1] Dmitriev A.V., Zvyagin I.P., Current trends in the physics of thermoelectric materials, Physics-Uspekhi 53 (2010), n.8, 789803

[2] Nayak J., Sahub S.N., Kasuya J., Nozakia S., CdS-ZnO composite nanorods: Synthesis, characterization and application for photocatalytic degradation of 3,4-dihydroxy benzoic acid, Applied Surface Science 254 (2008), 7215-7218

[3] Ning T., Gao P., Wang W., Lu H, Fu W., Zhou Y., Zhang D. Bai X, Wang E., Yang G., Nonlinear optical properties of composite films consisting of multi-armed CdS nanorods and ZnO, Optical Materials 31 (2009), 931-935

[4] Nayak J., Lohani H., Bera T.K., Observation of catalytic properties of $\mathrm{CdS}-\mathrm{ZnO}$ composite nanorods synthesized by aqueous chemical growth technique, Current Applied Physics 11 (2011), 93-97

[5] Yang Y., Pradel K.C., Jing Q., Wu J.M., Zhang F., Zhou Y., Zhang Y., Wang Z.L., Thermoelectric Nanogenerators Based on Single Sb-Doped $\mathrm{ZnO}$ Micro/Nanobelts, ACS Nano 6 (2012), n.8, 6984-6989

[6] Thompson R.S., Li D., Witte C.M., Lu J.G., Weak Localization and Electron-Electron Interactions in Indium-Doped $\mathrm{ZnO}$ Nanowires, Nano Letters 9 (2009), 3991-3995

[7] Yang Y., Qi J., Liao Q., Zhang Y., Tang L., Qin Z., Synthesis and Characterization of Sb-Doped ZnO Nanobelts with SingleSide Zigzag Boundaries, The Journal of Physical Chemistry C 112 (2008), 17916-17919

[8] Zhou M., Zhu H., Jiao Y., Rao Y., Hark S., Liu Y., Peng L., Li Q., Optical and Electrical Properties of Ga-Doped ZnO Nanowire Arrays on Conducting Substrates, The Journal of Physical Chemistry C 113 (2009), 8945-8947

[9] Cuscó R., Alarcón-Lladó E., Ibanez J., Artús L., Jiménez J., Wang B., Callahan M.J., Temperature dependence of Raman scattering in ZnO, Physical Review B 75 (2007), art. no. 165202 